\title{
Ability of pharmacy students to assess their learning
}

\author{
Suleiman I. Sharif (iD), Abduelmula R. Abduelkarem iD \\ Department of Pharmacy Practice \& Pharmacotherapeutics, College of Pharmacy, University of Sharjah, United Arab Emirates
}

\author{
Keywords \\ Learning \\ Neurodegenerative disorder \\ Pharmacy student \\ Self assessment
}

\section{Correspondence}

Prof. Suleiman Ibrahim Sharif Department Pharmacy Practice \& Pharmacotherapeutics

College of Pharmacy

University of Sharjah

Sharjah, PO Box 27272

United Arab Emirates

sharifsi@sharjah.ac.ae

\begin{abstract}
Objective: The aim of the study was to evaluate the ability of pharmacy students to assess their learning. Methods: Without pre-class preparation or access to learning resources, third-year pharmacy students were asked to list in preset templates the important points of topics that were covered two weeks earlier including Alzheimer's, Huntington's chorea and Parkinson's diseases, structure short essay questions guided by these lists and answer them. In the first section, students worked individually while in the second and third sections they worked in groups of four. At the end of each session, students were asked to fill in a pre-piloted ethically approved questionnaire on their perception of the present exercise and learning strategies and examinations. Results: The majority of participants ( $n$ : $51 ; 85 \%$ ) were females and with GPAs ranging from 2.5-4. The important points listed by students focused on the aetiology and treatment of the disorders. However, the questions framed by grouped students and their answers were more thorough and well organised. Half of the participants reported the aim of tests was to improve their learning and the majority (93\%, $85 \%$ and $85 \%)$ of students preferred pre-scheduled tests, paper examinations and lectures using PowerPoint presentations respectively. In their reflection on the exercise, most students enjoyed it and found it effective in enhancing their learning. Conclusion: The present pedagogy enhances learning, writing skills, group collaboration and team spirit. Its application in other classes and topics would strengthen its value in enhancing learning.
\end{abstract}

\section{Introduction}

In any given course, instructors administer tests that are designed to assess the level of student's achievement of the learning objectives of the course and to assign marks for grading the students' performance. On the other hand, students deal with tests with the main aim of generating marks. It has been suggested that tests can aim at increasing learning outcomes (Roediger \& Karpicke, 2006a; Roediger \& Karpicke, 2006b). Most national and international accreditation standards focus on encouraging critical thinking, active self-directed and longlife learning through innovative teaching and learning strategies (Standards for licensure and accreditation, 2011; Accreditation Council for Pharmacy Education, 2016). Expansion in content knowledge in the pharmacy profession and in health care in general progress at a faster rate than that at which curricula could be updated to ensure exposure of learners to comprehensive knowledge and the skills necessary for practising the profession (Hagemeier \& Mason, 2011). The ability of students to gain insight into their knowledge and skills of a particular topic(s) is an important component of professional self-assessment. However, the terms selfassessment, self-reflection, and self-evaluation are widely used and interchangeable. To enhance students' knowledge, skills, attitude, and values, students need to be trained on how to direct their self-learning to important aspects of each topic guided by the learning objectives of that particular topic or course. They also need to assess their own level of knowledge that they gained through lectures, problem-based and/or teambased learning and any other teaching and learning strategies. There are differences in attitudes, beliefs, and experiences of older faculty as compared to their millennial students and are related to generation characteristics (Pick, Begley \& Augustine, 2017). Such generational differences are related to teaching and learning (Black, 2010). At the college of pharmacy, University of Sharjah (UoS), the course of Central Nervous 
System (CNS) pharmacology is taught during the spring semester of each academic year for third-year students. The study plan of the bachelor pharmacy (170 credit hours) program is spread over 5 -years. The course is 3 $(2+1)$ credit hours, with two credit hours for theory and one credit hour for practical/tutorial classes. The learning/teaching strategies adapted in the CNS course of pharmacology include didactic lectures, team-based learning and practical classes. Course material is posted on Blackboard, a type of Virtual Learning Environment (VLE) platform, one week prior to the theory classes. In an attempt to encourage students to understand and appreciate the course design, the present exercise was carried out two weeks after initial lectures on neurodegenerative disorders, including pharmacotherapeutics of Alzheimer's, Huntington's chorea and Parkinson's diseases. In this "examine yourself" exercise, the authors evaluated the ability of third-year pharmacy students at the UoS to assess their learning of topics covered two weeks earlier by listing the most important points and framing essay questions that they believe examine the most important parts of the topics.

\section{Methods}

The aim of the study was to evaluate the ability of the third-year pharmacy students to assess their learning. Topics on neurodegenerative disorders are taught within the course of CNS (Pharmacology-IIA). Powerpoint presentations of pharmacotherapeutics of Parkinson's, Huntington's chorea and Alzheimer's diseases were posted on Blackboard and discussed two weeks prior to the exercise session. An instruction sheet summarising the learning objectives of the course was prepared and distributed to the students in the class. They were asked to list the important points of each disease and its pharmacotherapeutics as a guide to help them in structuring short essay questions on each of the three disorders. Students were asked to frame one short essay question for Alzheimer's and Huntington's chorea diseases and three short essay questions for Parkinson's disease. Thereafter, students were asked to answer their structured questions and fairly and responsibly correct them. All students registered in this course during the study period participated in this activity without any preclass preparation. Third-year students registered in the course are distributed in three sections. In the first section, the class of 20 students participated, and each conducted the exercise individually; the other two sections were composed of 16 and 24 students each and were asked to conduct the exercise in groups of 4 each. No access was allowed to textbooks, lecture notes or the internet.

\section{The questionnaire}

At the end of the activity, students were asked to answer an anonymous pre-piloted ethically approved questionnaire that can be answered within 10 minutes. Questions in the survey covered gender, Grade Point Average (GPA), the aim of student's quizzes, midterm and final examinations to improve learning, generate marks or both. Whether they prefer to pop up or scheduled quizzes, the type of exam they prefer (paper exam, oral exam or online exam, the sources for learning they use (lecture notes, textbooks or both) were also included in the survey. Their preferred teaching/learning methods were questioned (lectures (PowerPoint presentation), flipped lectures, team-based learning, and problem-based learning), whether the present self-assessment exercise affected their perceptions of learning, and whether they support such self-assessment of learning as a teaching/learning strategy if the instructor of the course provides feedback and grades for their efforts.

\section{Analysis}

Responses were encoded, and the data were analyzed using Statistical Package for the Social Sciences (IBM SPSS Statistics for Windows, version 20.0). Students' responses are displayed as frequency and percentage, and $95 \% \mathrm{Cl}$ was calculated for the response of students to questions on aspects of teaching/learning outcomes.

\section{Ethical approval}

Ethical approval was obtained from the Ethical Committee of the University of Sharjah. Students were provided with an information sheet indicating that the nature and purpose of the survey and written consent were taken as approval to willingly participate in the study.

\section{Results}

Both individual (20) and grouped (40) students focused on listing the aetiology and drug treatment of Alzheimer's, Huntington's chorea and Parkinson's disorders as a guide to later frame short essay questions. Interestingly, for the Parkinson's disease topic, individual students listed the aetiology of the disorder, risk factors, signs and symptoms, disease progression and drug treatment. However, grouped students, in addition to these points, also listed neuroanatomy, dopaminergic and cholinergic neurotransmitter balances, cardinal symptoms of the disorder, drug administration and on-off phenomena, drug interactions and side effects. Table I summarises important points listed for each disorder by individual and group students. 
Table I: Important points listed for each disorder by students

\begin{tabular}{|c|c|c|}
\hline $\begin{array}{l}\text { Neurodege } \\
\text { nerative } \\
\text { disorder }\end{array}$ & $\begin{array}{l}\text { Individual } \\
\text { students }\end{array}$ & Group students \\
\hline Alzheimer & $\begin{array}{l}\text { - Causes of the } \\
\text { disorder } \\
\text { - Drug } \\
\text { treatment }\end{array}$ & $\begin{array}{l}\text { - Characteristics of } \\
\text { disorder } \\
\text { - Drug treatment }\end{array}$ \\
\hline $\begin{array}{l}\text { Huntington } \\
\text { Chorea }\end{array}$ & $\begin{array}{l}\text { - Aetiology of } \\
\text { disorder } \\
\text { - Pharmacothe } \\
\text { rapeutics }\end{array}$ & $\begin{array}{l}\text { - Pathophysiology of } \\
\text { disorder } \\
\text { - Drug treatment }\end{array}$ \\
\hline Parkinson & $\begin{array}{l}\text { - Aetiology of } \\
\text { disorder } \\
\text { - Risk factors } \\
\text { - Signs and } \\
\text { symptoms } \\
\text { - Disease } \\
\text { progression } \\
\text { - Drug } \\
\text { treatment }\end{array}$ & $\begin{array}{l}\text { - Neuroanatomy of } \\
\text { - substantia nigra } \\
\text { - Dopaminergic versus } \\
\text { cholinergic balance } \\
\text { - Risk factors } \\
\text { - Cardinal symptoms } \\
\text { - Drug holiday } \\
\text { - On-off phenomenon } \\
\text { - Drug treatment, drug } \\
\text { interactions and side } \\
\text { effects }\end{array}$ \\
\hline
\end{tabular}

\section{Short essay questions structured by students}

A sample of short essay questions structured by both individual and group students are shown in Table II. Questions structured by grouped students were more learning objective-oriented and covered various important points than those by individual students. Individual student's questions covered definitions and strategies for therapy of Alzheimer's disease and for Huntington's chorea defects in the neurochemistry of the brain and classes of drugs used in treatment and reasons. For Parkinson's disease, their questions focused on risk factors, symptoms, therapeutic strategies and drug combinations used for treatment. Grouped students structured similar questions on Alzheimer's and Huntington's chorea and added questions on the main differences between the disorders. Questions by grouped students on Parkinson's disease were variable and covered descriptions of the central dopaminergic pathways, risk factors, symptoms, variations in Parkinsonism symptomatology, advantages and disadvantages of monotherapy and combination therapies, and on-off phenomenon.

Table II: Samples of students' structured short essay questions

\begin{tabular}{|c|c|c|}
\hline Neurodegenerative disorder & $\begin{array}{l}\text { Short questions structured by } \\
\text { individual students }\end{array}$ & $\begin{array}{l}\text { Short questions structured by } \\
\text { group students }\end{array}$ \\
\hline Alzheimer's & $\begin{array}{l}\text { - Define the disease and the strategies of } \\
\text { treatment. }\end{array}$ & $\begin{array}{l}\text { - Discuss the neurochemical defect in } \\
\text { Alzheimer disease } \\
\text { - Mention classes of drugs used in } \\
\text { treatment of Alzheimer's disease }\end{array}$ \\
\hline Huntington's Chorea & $\begin{array}{l}\text { - Is Huntington's chorea related to defect in } \\
\text { brain neurochemistry? } \\
\text { - What causes Huntington's chorea? } \\
\text { - What class of drugs used in Huntington's } \\
\text { chorea and why? }\end{array}$ & $\begin{array}{l}\text { Mention the characteristics of the } \\
\text { disease. } \\
\text { - Discuss drug treatment of the } \\
\text { disorder. } \\
\text { - What are the main differences } \\
\text { between the disorder and Parkinson's } \\
\text { disease? }\end{array}$ \\
\hline Parkinson's & $\begin{array}{l}\text { - What are the risk factors for Parkinson's } \\
\text { disease? } \\
\text { - List the symptoms of Parkinson's disease. } \\
\text { - Mention the various strategies for therapy } \\
\text { of Parkinson's disease. } \\
\text { - Why we should use a combination of L- } \\
\text { dopa plus carbidopa for treatment of } \\
\text { Parkinson's disease? }\end{array}$ & $\begin{array}{l}\text { - Define the central dopaminergic } \\
\text { pathways? } \\
\text { - What are the risk factors for } \\
\text { Parkinson's disease? } \\
\text { - What are the main differences } \\
\text { between Parkinson's disease and } \\
\text { - Parkinsonism? } \\
\text { - What are the main symptoms of } \\
\text { Parkinson's disease? } \\
\text { is not favored? } \\
\text { - Discuss the advantages of } \\
\text { combination therapy with L-dopa - } \\
\text { carbidopa. } \\
\text { - What is meant by on-off } \\
\text { phenomenon? }\end{array}$ \\
\hline
\end{tabular}

\section{Comparison of individual and grouped students}

Comparison of samples of answers provided by both individual and grouped students to their own short questions is summarised in Table III. Again, answers provided by grouped students were well written and more detailed as compared to fragmented brief answers given by individual students. 


\section{Questionnaire responses}

The majority (51.8\%) of students was females, and 3 $(5.0 \%)$ had a GPA less than 2. Half of the students ( $n: 30$; $50.0 \%$ ) included in the study indicated that their aim of tests is to improve learning, while for 26 (43.3\%), the aim was to generate marks. Again, the majority prefer scheduled ( $: 56 ; 93.3 \%$ ) and paper examinations ( $\mathrm{n}: 54$; $90.0 \%)$. Regarding the students' sources of learning, about two thirds ( $\mathrm{n}: 38 ; 63.3 \%$ ) prefer either lectures notes or textbooks.

Table III: Samples of students' answers to their structured questions

\begin{tabular}{|c|c|c|}
\hline Question & Individual answers & Group answers \\
\hline $\begin{array}{l}\text { What are the characteristics of } \\
\text { Alzheimer's disease and what treatment } \\
\text { strategies? }\end{array}$ & $\begin{array}{l}\text { 1.Loss of cholinergic neurons } \\
\text { 2.accumulation of } \beta \text {-amyloid } \\
\text { 3. Formation of neurofibrillary tangles. } \\
\text { Treatment: Donepizole or memantine }\end{array}$ & $\begin{array}{l}\text { The disease is palliative, there is no cure } \\
\text { treatments only improves the symptoms. The } \\
\text { defect is manifested in the cholinergic } \\
\text { transmission. The etiology of the disease is mainly } \\
\text { due to accumulation of } \beta \text {-amyloid and the } \\
\text { formation of neurofibrillary tangles. Treatment } \\
\text { depends on increasing the cholinergic activity by } \\
\text { using anticholinesterase agents or blocking NMDA } \\
\text { receptors for glutamate. }\end{array}$ \\
\hline
\end{tabular}

\begin{tabular}{|c|c|c|}
\hline $\begin{array}{l}\text { What are the characteristics of } \\
\text { Huntington's chorea? }\end{array}$ & $\begin{array}{l}\text { In Huntington's chorea, the dopamine is } \\
\text { intact but there is low dopamine and GABA } \\
\text { amount. }\end{array}$ & $\begin{array}{l}\text { In Huntington's chorea, there is intact dopaminergic } \\
\text { transmission but the defect is in GABA and } \\
\text { acetylcholine. Haloperidol as treatment reduces } \\
\text { dopaminergic activity and releases GABA. }\end{array}$ \\
\hline $\begin{array}{l}\text { What are the differences between } \\
\text { Parkinson's disease and Parkinsonism? }\end{array}$ & $\begin{array}{l}\text { Both are characterized by loss of } \\
\text { dopaminergic neurons but the } \\
\text { Parkinsonism is caused by drugs like } \\
\text { physostigmine, reserpine and } \\
\text { antipsychotics. }\end{array}$ & $\begin{array}{l}\text { The difference between Parkinson's disease and } \\
\text { Parkinsonism lies in the first being precipitated by } \\
\text { the progressive degeneration of dopaminergic } \\
\text { neurons in CNS while the second is drug-induced } \\
\text { e.g. antipsychotics. }\end{array}$ \\
\hline What is meant by drug holiday? & $\begin{array}{l}\text { It will increase responsiveness to doses } \\
\text { lesser than those the patient was taking } \\
\text { before the holiday. }\end{array}$ & $\begin{array}{l}\text { To improve the reduction in responsiveness to L- } \\
\text { dopa, a drug holiday is followed by stopping the } \\
\text { drug for 3-21 days. After this holiday there will be } \\
\text { better response of the patient to doses lower than } \\
\text { that before the holiday. Risk of this drug holiday is } \\
\text { severe depression of the patient and pulmonary } \\
\text { pneumonia because of excessive immobility and } \\
\text { difficulty to swallow the profuse saliva. }\end{array}$ \\
\hline $\begin{array}{l}\text { What are the symptoms of Parkinson's } \\
\text { disease? }\end{array}$ & Tremor, bradykinesia, rigidity & $\begin{array}{l}\text { Cardinal symptoms of Parkinson's disease are } \\
\text { tremor, rigidity and bradykinesia. Other symptoms } \\
\text { include gait disorder, drippling saliva, irregular } \\
\text { hand writing. }\end{array}$ \\
\hline
\end{tabular}

When the students included in the study were asked about the preferred form of teaching/learning strategy, the majority $(n: 51 ; 85.0 \%)$ reported that they prefer lectures as a PowerPoint presentation. Of the sample, only $2(3.3 \%), 6(10.0 \%)$, and $1(1.7 \%)$ reported a preference for flipped lectures, team-based learning, and problem-based learning, respectively, as their preferred teaching and learning methods. Almost all ( $n: 59 ; 98.3 \%$ ) believed that self-examining their knowledge improved their learning. About two thirds ( $n: 39 ; 65.0 \%$ ) approved the application of the present self-assessment exercise provided that the questions and answers are graded by the instructor. Responses of students to questions on various aspects of teaching/learning strategies are shown in Table IV.
Selected student reflection comments on their selfassessment of learning are listed in Table $\mathrm{V}$. The collected data was subjected to thematic analysis. The most prominent theme from students in both groups is their agreement that the self-assessment of their learning is a useful experience, particularly when run as a group exercise, where they can learn from each other and discuss the topics and share information. However, individually working students believed that their performance would have been much better if they had pre-class preparation. All students refrained from correcting the answers to their own framed questions and, for fairness prefer the course instructor to correct their answers. 
Table IV: Responses of students to questions on various aspects of teaching/learning strategies

\begin{tabular}{|c|c|c|}
\hline Question & $\begin{array}{c}\text { Frequency (\%) } \\
\mathrm{n}: 60\end{array}$ & $95 \% \mathrm{Cl}$ \\
\hline \multicolumn{3}{|l|}{ Gender } \\
\hline - Male & $6(10 \%)$ & \\
\hline - Females & $51(85 \%)$ & \\
\hline \multicolumn{3}{|l|}{ GPA } \\
\hline$\bullet<2$ & $3(5 \%)$ & \\
\hline - $2-2.4$ & $7(11.7 \%)$ & \\
\hline - $2.5-2.9$ & $11(18.3 \%)$ & \\
\hline - $3-3.5$ & $16(26.7 \%)$ & \\
\hline - $3.6-4$ & $21(35 \%)$ & \\
\hline \multicolumn{3}{|c|}{ What you aim at in quizzes, midterm and final exams? } \\
\hline - Improve learning & $30(50 \%)$ & $(37.4-62.6)$ \\
\hline - Generate grades & $26(43.3 \%)$ & $(30.8-55.8)$ \\
\hline - Both & $4(6.7 \%)$ & $(1.0-12.9)$ \\
\hline \multicolumn{3}{|l|}{ What do you prefer for quizzes? } \\
\hline - Pop up quizzes & $4(6.5 \%)$ & $(1.0-12.9)$ \\
\hline - Scheduled quizzes & $56(93.3 \%)$ & (87.1-99.6) \\
\hline \multicolumn{3}{|l|}{ What type of exam do you prefer? } \\
\hline - Paper exam & $54(90 \%)$ & $(82.5-97.5)$ \\
\hline - Oral exam & $1(1.7 \%)$ & $(1.0-4.8)$ \\
\hline - Online exam (Exam soft) & $5(8.3 \%)$ & $(1.4-15.3)$ \\
\hline \multicolumn{3}{|l|}{ What are your sources of learning? } \\
\hline - Lecture notes & $17(28.3 \%)$ & $(16.9-39.7)$ \\
\hline - Text books & $5(8.3 \%)$ & $(1.4-15.3)$ \\
\hline - Both & $38(63.3 \%)$ & $(51.2-75.3)$ \\
\hline \multicolumn{3}{|c|}{ What is your preferred form of teaching/learning? } \\
\hline - Lectures (Power point presentation) & $51(85 \%)$ & $(76.0-93.9)$ \\
\hline - Flipped lectures & $2(3.3 \%)$ & $(1.0-7.8)$ \\
\hline - Team-based learning & $6(10 \%)$ & $(2.5-17.5)$ \\
\hline - Problem-based learning & $1(1.7 \%)$ & $(1.0-4.8)$ \\
\hline \multicolumn{3}{|c|}{ Do you think self-examining your knowledge helps you improve } \\
\hline your learning? & $59(98.3 \%)$ & $(95.0-100.0)$ \\
\hline - Yes & $1(1.7 \%)$ & $(1.0-4.8)$ \\
\hline - No & & \\
\hline \multicolumn{3}{|c|}{$\begin{array}{l}\text { Would you approve of "Examine yourself "practice provided that } \\
\text { the instructor distributes the marks according to his/her } \\
\text { judgment of the importance of the questioned part of the topic? }\end{array}$} \\
\hline - Yes & $39(65 \%)$ & $(52.89-77.2)$ \\
\hline - No & $21(35 \%)$ & $(22.9-47.1)$ \\
\hline
\end{tabular}

\section{Table V: Selected student reflection comments}

- "It is a good practical experience. I like it, it is effective as this exercise helps us to enhances our learning and increase our knowledge"

- "It is a helpful practice that let one test his/her knowledge before exams and pinpoint parts to revise and focus on"

- "Useful experience, particularly when run as a group, we can learn from each other and discuss the topics and share information"

- "I like this session as I benefited from group discussion and sharing knowledge. I hope we follow the same with other topics in the course"

- "A good strategy to keep students up to date with class lectures. Self-examining ourselves helps in enhancing our learning"

- "I believe it is a great way of increasing the student's confidence and knowledge but may not be effective or accurate if students were not really prepared for the exercise"

- "It was not so satisfying to me because I was not fully prepared for the session but overall it is a good idea to help gain experience and more knowledge. I think if I was prepared, I would have performed better"

- "I like it but to correct our own answers of questions we structured may not be a good idea, as not all students will be honest and fair"

- I like the exercise as an innovative strategy to enhance our learning. It helps us brainstorming on important points of the topic and helps us to know where we stand and how we should improve our knowledge"

- "This exercise is a practical strategy that gets us out of the stress of lectures and help as a revision class"

- "It is completely practical and fair for me to check my missing points and for the courses' instructor to know what topics we have problems with"

- "Examine yourself helps a lot in learning and knowing your weaknesses in some parts of the topic so we can go back and improve your knowledge in that part" 


\section{Discussion}

The aim of this study was to evaluate the ability of third-year pharmacy students to assess their learning. Students were asked to list the points they think are important for neurodegenerative disorders, then frame short essay questions and answer and correct them. This task was carried out by students without pre-class preparation for the topics that were covered one week earlier. Among the benefits of active learning is enhanced understanding of topics, improved critical thinking skills and greater retention of information (Pick, Begley \& Augustine, 2017). In this study, students working in small groups of four and also students working individually prepared similar lists of important points of Huntington's chorea and Alzheimer's diseases but for Parkinson's disease, lists prepared by grouped students covered more important topics that were focused and well organized. Working in small groups has been reported to enhance engagement, participation, discussion and collaboration (Michaelsen et al., 2009).

Innovative strategies of learning, including problembased and team-based learning, have been widely implemented in, among others, healthcare education and proved effective in fostering active learning. Teambased learning has been reported to markedly enhance student's understanding, and retention and its implementation has been frequently advocated (Bloom, 1956; Andersen \& Krathwohl, 2001; Michaelsen, Knight \& Fink, 2004). Regardless of the teaching and learning strategy followed, the new approach in the present study aimed at evaluating the ability of third pharmacy students to assess their learning. This encourages students to enhance their writing, communication skills and critical thinking in addition to sharing knowledge and revise their courses to improve their academic and professional performance. Implementation of such strategy of learning in the classroom helps students to acquire a technique of organising their knowledge of topics according to the importance of information needed for the best practice skill of their profession.

There are described generational differences between millennial students and faculty with regard to teaching and learning (Black, 2010). Today's students prefer working in groups, actively engage in learning and utilize the technology which they master. Among the techniques students use in preparing for a test is anticipating the content of the test questions and studying accordingly (Sansgiry, Bhosle, \& Sail, 2006). Results of the present exercise illustrated that students without pre-class preparation were able to list the important points of neurodegenerative disorders, a step towards constructing meaningful short essay questions covering these points. While doing this, students were kept engaged in assessing their level of retention of knowledge. Allowing students to structure a set of questions guided by their listed important points of the topic enabled them to appreciate the assessment preparation of exams that cover the learning objectives of the topics. Again, grouped students, through discussion and sharing knowledge, produced better sets of questions than students working individually. This further supports the benefit of working in small groups. In addition, the competitiveness between groups enriched the outcomes of the exercise. Further, the present study also provided information on how instructors can create a learning environment that might improve student satisfaction, enhance attendance and keep them undistracted.

Educational outcomes have become increasingly focused on teaching methods that increase communication, critical thinking, problem-solving, and self-learning skills (Accreditation Council for Pharmacy Education (ACPE), 2006; CAPE Educational Outcomes, 2014). Answers of students to their own structured questions were reasonably stated with better and complete answers given by group students. Test competence is the single most important factor that may help distinguish students with academic performance (Sansgiry, Bhosle, \& Sail, 2006). The performance of grouped students in a quiz held one week later on the same topics was again better than the majority of those who worked individually. Such observations stress the importance of group discussion and sharing of knowledge on enhancing the level of knowledge and retention. Educators should be aware of the fact that students of any speciality have to be assessed in quizzes, midterm and final exams, and their principal concern is to generate marks and improve their grades, and such an exercise throughout the course would certainly prove helpful in improving learning outcomes. In the present exercise, none of the participants attempted correcting their own answers, and they admitted that they find it unfair as they may be self-biased.

In the feedback, almost all students stated preferred this approach where they were able to assess their learning. Satisfaction of the students with the outcomes of the exercise of self-assessment would make it possible for them to self-apply it to other topics in the course and to appreciate the efforts of their teachers. 


\section{Limitations}

A major limitation of this study is the small number of participant students and the focus on only one topic of the overall programme.

\section{Conclusion}

The present pedagogy, in addition to enhancing learning, writing skills, group collaboration and team spirit, allows students to have an insight into the art of structuring exam questions and appreciate the correction and grading of exams by their instructors. Students in answering their own questions can judge according to their level of retention whether their answers are adequate or deficient. They can also pinpoint deficiencies in a certain topic and focus on enhancing their knowledge. Future plans include expanding the present approach to be conducted in several classes of students using different topics at different times. Moreover, the promising results obtained suggest conducting the same exercise on different topics and in several classes in order to recommend this learning strategy in the university system. The present pedagogy, in addition to enhancing learning, writing skills, group collaboration and team spirit, allows students to have an insight into the structuring of exam questions and appreciate the correction and grading of exams by their instructors.

\section{Acknowledgement}

This article is dedicated to the memory of the late Prof. Abubaker A. Bashir, who passed away on $18^{\text {th }}$ July 2020 and shall always be remembered as a brother, friend and eminent academician.

\section{Funding}

The study received no grant from any funding agency.

\section{Conflict of interest}

The authors declare no conflict of interest.

\section{References}

Accreditation Council for Pharmacy Education (ACPE). (2006). Accreditation Standards and Guidelines for the Professional Program in Pharmacy Leading to the Doctor of Pharmacy
Degree. Available at: http://www.acpeaccredit.org/pdf/ACPE_Revised_PharmD_Standards_Adopte d_Jan152006.pdf

Accreditation Council for Pharmacy Education (2016). Available at: https://www.acpeaccredit.org/pdf/Standards2016FINAL

American Association of Colleges of Pharmacy. (2014). Center for Advancement of Pharmaceutical Education (CAPE) Educational Outcomes. American Journal of Pharmaceutical Education; 78 (10), Article 185. Available at: https://www.ajpe.org/content/ajpe/78/10/185.full.pdf

Andersen, L.W. \& Krathwohl, D.R. (2001). A taxonomy for learning, teaching, and assessing: A revision of bloom's taxonomy for educational objectives. New York: Longman

Black, A. (2010). Gen Y: Who They Are and How They Learn Educational Horizons. Available at: http://iles.eric.ed.gov/fulltext/EJ872487.pdf

Bloom B.S. (1956). Taxonomy of educational objectives, Handbook I: Cognitive Domain, 1st edition. White Plains, New York: Longman

Hagemeier, N.E. \& Mason, H.L. (2011). Student pharmacists' perceptions of testing and study strategies. American Journal of Pharmaceutical Education; 75 (2): Article 35. https://doi.org/10.5688/ajpe75235

Michaelsen, L.K., Knight, A.B.\& Fink, L.D. (2004). Team-Based Learning: A Transformative Use of Small Groups in College Teaching. Sterling, VA: Stylus Publishing

Michaelsen L, Parmelee D, McMahon KK \& Levine RE. (2007). Team-based learning for health professions education. Sterling: Stylus

Pick, AM, Begley, KJ. \& Augustine, S. (2017). Changes in teaching strategies to accommodate a new generation of learner: A case study. Pharmacy Education, 2017; 17 (1):9599

Roediger, H. \& Karpicke, J. (2006). The power of testing memory: basic research and implications for educational practice. Perspective on Psychological Science; 1(3):181-210. https://doi.org/10.1111/j.1745-6916.2006.00012.x

Roediger, H. \& Karpicke, J. (2006). Test-enhanced learning: taking memory tests improves long-term retention. Psychological Science; $\quad 17(3): 249-255$. https://doi.org.10.1111/j.1467-9280.2006.01693.x

Sansgiry, S.S., Bhosle, M. \& Sail, K. (2006). Factors that affect academic performance among pharmacy students. American Journal of Pharmaceutical Education; 70 (5) Article 104

Standards for licensure and accreditation. (2011). Available at: https://www.caa.ae/caa/images/Standards2011.pdf

Wiener, H., Plass, H. \& Marz R. (2009). Team-based learning in intensive course format for first-year medical students. Croatian Medical Journal; 50: 69-76 